\title{
Investigating Student's Satisfaction and Acceptance of Digital Technology in Higher Education in Indonesia
}

\author{
Mar'atus Sholikah ${ }^{1}$, Dwi Harsono ${ }^{1}$ \\ ${ }^{1}$ Universitas Negeri Yogyakarta, Colombo Street No. 1, Yogyakarta, Indonesia
}

\begin{abstract}
The use and acceptance of digital technology, especially electronic learning in education, is essential for increasing student's satisfaction. Electronic learning is a process to use digital technology in education. This study's objectives are figuring out the adoption of electronic learning systems using the UTAUT model with student satisfaction as the mediation. We used AMOS 24 to interpret quantitative data. This study conducted cluster sampling with a total number of respondents as many as 197 students from seven state universities in Indonesia, namely Universitas Negeri Padang, Universitas Negeri Jakarta, Universitas Diponegoro, and Universitas Negeri Semarang, Universitas Sebelas Maret, Universitas Gadjah Mada, and Universitas Negeri Yogyakarta. The findings indicated that all acceptance factors in electronic learning, such as PER, EFF, SOC, and FAC, influence electronic knowledge acceptance, referring to student satisfaction. This research contributes to the use of electronic learning in college.
\end{abstract}

Keywords - Digital technology, E-learning, UTAUT model, Student satisfaction.

\section{Introduction}

The development of digital technology and the internet in the education field is increasingly becoming very important, especially in the learning

DOI: 10.18421/TEM102-56

https://doi.org/10.18421/TEM102-56

Corresponding author: Mar'atus Sholikah, Universitas Negeri Yogyakarta, Yogyakarta, Indonesia Email: maratussholikah.2019@student.uny.ac.id

Received: 13 December 2020.

Revised: 29 April 2021.

Accepted: 04 May 2021.

Published: 27 May 2021.

(c) BY-NC-ND (C) 2021 Mar'atus Sholikah \& Dwi Harsono; published by UIKTEN. This work is licensed under the Creative Commons Attribution-NonCommercial-NoDerivs 4.0 License.

The article is published with Open Access at www.temjournal.com process. Some researchers empirically reveal that digital technology and the internet are perfect learning tools that offer students benefits and convenience [1]. Consequently, educators are encouraged to utilize technology and the internet in their teaching as tools to facilitate the learning process. The development met with the Decree of the Minister of National Education on September 24, 2001, regarding calls for higher education to organize education based on distance learning and digital technology. In this case, various digital technologybased education services, such as electronic knowledge, are available in higher education institutions.

In agreement with Luaran et al., electronic learning is learning by utilizing an online system such as the internet, computer, multimedia technologies [2]. Definition of e-learning is a pedagogy that applies digital technology [3]. Those definitions explain that e-learning is an educational system supported by digital technology, such as the internet, web, and computers. Furthermore, the system supports teaching and learning processes to students in conveying the teaching material.

E-learning is currently one of the most advanced and widely used features in education. Many use electronic learning to improve performance, insight, and skills [4]. Conforming to Alexander, electronic learning can boost the learning quality, access to training and education and increase the learning process's effectiveness. Then we conclude that electronic knowledge can be a beneficial device and help the teaching and learning process.

However, the implementation of e-learning in reality still faces several problems, particularly in the use and acceptance of students and educators. Some researchers indicate that the acceptance of digital technology-based learning has become an obstacle to e-learning implementation [5]. Students' acceptance of electronic learning becomes an important step that needs to be studied to ensure the successful application of e-learning. Therefore, understanding and identifying electronic learning acceptance factors by students is crucial to be discussed and investigated. 
Culture is the most influential factor for individual attitudes in accepting and using various technologies [6]. Previous studies found cross-cultural broadening of models in acceptance of technology, like technology acceptance models [7]. However, the Unified Theory of Acceptance and Use of Technology (UTAUT) model is a newer instrument that desegregates reasoned action theory, motivational models, and acceptance models [8]. The UTAUT model consists of some constructs, namely performance expectancy, effort expectancy, attitude towards using technology, social influence, facilitating conditions, self-efficacy, anxiety, and behavioral intention to use the system.

Empirically, factors of technology acceptance in education using the UTAUT model have not been much studied. Therefore, we use the UTAUT model with four primary constructs: performance expectancy, effort expectancy, social influence, and facilitating conditions. Also, this research used student satisfaction as a mediating variable. With this background, this study investigates how UTAUT model factors affect digital technology in students mediated by student's satisfaction.

\section{Literature Review}

\section{Student Satisfaction}

Satisfaction is the customer attitudes towards the provider as a whole. Still, it explains emotion's reaction to the difference between sacrificing and utility on some needs, goals, or desires. In line with Weerasinghe \& Fernando, satisfaction is the pleasure of achievement [9]. Satisfaction is the consumer's perception of price, time, suitability, responsibility, professionalism, comfort. It can also be a combination of these.

According to Kara, an individual will know customer satisfaction if they have used products from quality services [10]. Therefore, according to Yusnaini, customer's satisfaction tries to eliminate the gap between expectation and circumstances. In education, satisfaction (SAT) is the attitude of experiencing educational services felt and received [11]. In agreement with Zaied, enjoyment and selfefficacy become the indicators to evaluate student's satisfaction [12].

\section{Electronic Learning}

The abbreviation of electronic learning is elearning. It is a digital device used to support learning activities or specific academic frameworks. As stated in Gilbert, E-learning is defined as the transmission of learning material via electronics such as the internet, radio, television, CD ROM. Besides, the meaning of e-learning is sending learning material process by utilizing technology to anyone, anywhere, and anytime, so the learning environment is flexible and distorted. Flexible and open in this case are interpreted as student freedom in terms of time, place, speed, content, learning style, evaluation, collaborative learning, and independent learning.

The modes of presentation of e-learning have three categories: first, asynchronous, a system of elearning where content is available and accessible from anywhere and anytime. Second, synchronous, which leads to e-learning, requires educators and students to live near different geographies. Third, blended, an e-learning system combines asynchronous, synchronous, and conventional classes.

\section{Digital Technology-Based learning Acceptance}

Acceptance of technology by users becomes very important in ensuring the success of the system. Therefore, identifying what factors influence student's acceptance of digital technology-based learning systems becomes very important related to users' approval of the technology. Several studies discovered that there is still a problem in digital technology-based learning systems adoption, namely acceptance and use [13]. The researchers sought to establish the most dominant digital learning acceptance factors equally to overcome this problem: TAM, TRA, UTAUT, and TPB models [14]. According to Alamaiah \& Alismaiel, the UTAUT model testing the influence of technology acceptance quality is strongly affected by the system, idea, and service quality [15]. Quality of design, ideas and services has substantial power in stimulating students to use technology-based learning.

\section{The UTAUT Model}

The UTAUT model is one of the most recent technologies acceptance models. This model purposes of clarifying the user's intention to accept technology and improve their usage behavior. The UTAUT model has eight constructs in the UTAUT model, namely performance expectancy, effort expectancy, attitude towards using technology, social influence, facilitating conditions, self-efficacy, anxiety, and behavioral intention to use the system [16].

There are four dominant determinants in this model that influence behavioral intention to accept the technology, namely performance expectancy (PER), effort expectancy (EFF), social influence (SOC), and facilitating conditions (FAC). PER measures individual trust in using the system. To that end, individuals believe that system will help and enable the improvement of their performance. EFF is defined and related to the level of individual comfort 
in using the system. SOC is an individual's view of the method widely used by people. Meanwhile, FAC relates to organizational support for system use.

\section{Method}

This study used a quantitative method to measure and tests the influence between variables empirically. Questionnaires were distributed online for two weeks with several 23 statement items analyzed through some articles on the UTAUT model and student satisfaction. This study conducted cluster sampling with a total number of respondents as many as 197 students from seven state universities in Indonesia, namely Universitas Negeri Padang, Universitas Negeri Jakarta, Universitas Diponegoro, and Universitas Negeri Semarang, Universitas Sebelas Maret, Universitas Gadjah Mada, and Universitas Negeri Yogyakarta. Cluster sampling is very appropriate to determine the number of samples with a comprehensive data source. The number of state universities (PTN) in Indonesia is 122 units (Minister of Research Technology and Higher Education, 2019). Therefore, we took 7 out of 122 units in Indonesia randomly or randomly. Besides selecting respondents, which is based on the frequency of elearning usage, this study also works with three demographic data.

The respondents' demographic data are presented in Table 1, which shows that respondents are predominantly female, namely $70.05 \%$ and $29.95 \%$ male. The majority of respondents were also more than $55.33 \%$ of undergraduates. The age range is dominated at the age of 20-30 years.

Table 1. Demographic Data

\begin{tabular}{||cccc||}
\hline Demographics & Category & Frequency & \% \\
Gender & Male & 59 & 29.95 \\
& Female & 138 & 70.05 \\
Education Level & $\mathrm{S} 1$ & 109 & 55.33 \\
& $\mathrm{~S} 2$ & 88 & 44.67 \\
Age & $<20$ & 11 & 5.58 \\
& $20-30$ & 177 & 89.85 \\
& $31-40$ & 8 & 4,06 \\
& $>40$ & 1 & 0.51 \\
\hline
\end{tabular}

\section{Variable}

The independent variables in this study were PER EFF, SOC, and FAC. Meanwhile, BEH was a dependent variable, and the mediating variable was student satisfaction. PER have four indicators, namely utilization perception, increase effectiveness, productivity, and get information quickly. Four indicators measure EFF variables, namely ease for interaction, ease for learning, use straightforward, and ease to be an expert. SOC variables are assessed with three indicators, including coworker factor, support from influential people, and help. For FAC variables, it is measured by facilitating the situation and compatible devices. BEH variables use indicators such as Designing for long-term use and more often used. In comparison, the SAT variable is measured by self-efficacy and enjoyment. More clearly, the indicators on the research variables are described in Table 2.

Table 2. The indicator in research variables

\begin{tabular}{|c|c|c|c|}
\hline \multirow[t]{2}{*}{ Variables } & & Indicators & Source \\
\hline & PER1 & $\begin{array}{l}\text { Utilization } \\
\text { perception }\end{array}$ & \\
\hline \multirow{4}{*}{$\begin{array}{c}\text { Performance } \\
\text { expectancy } \\
\text { (PER) }\end{array}$} & PER2 & $\begin{array}{l}\text { Increase } \\
\text { effectiveness }\end{array}$ & $\begin{array}{l}{[8],} \\
{[16]}\end{array}$ \\
\hline & PER3 & Productivity & \\
\hline & PER4 & $\begin{array}{l}\text { Get information } \\
\text { easily }\end{array}$ & \\
\hline & EFF1 & Ease for interaction & \\
\hline \multirow{3}{*}{$\begin{array}{c}\text { Effort } \\
\text { expectancy } \\
(E F F)\end{array}$} & EEF2 & Ease for learning & \\
\hline & EFF3 & Use easily & \\
\hline & EFF4 & $\begin{array}{l}\text { Ease to be an } \\
\text { expert }\end{array}$ & \\
\hline \multirow{3}{*}{$\begin{array}{c}\text { Social } \\
\text { influence } \\
\text { (SOC) }\end{array}$} & SOC1 & Coworker factor & \\
\hline & SOC2 & $\begin{array}{l}\text { Support from } \\
\text { influential people }\end{array}$ & \\
\hline & SOC3 & Help is used & \\
\hline $\begin{array}{l}\text { Facilitating } \\
\text { conditions }\end{array}$ & FAC1 & $\begin{array}{l}\text { Facilitating the } \\
\text { situation }\end{array}$ & \\
\hline (FAC) & FAC2 & Compatible devices & \\
\hline $\begin{array}{l}\text { Behavioral } \\
\text { intention to }\end{array}$ & BEH1 & $\begin{array}{l}\text { Designing for long- } \\
\text { term use }\end{array}$ & \\
\hline use (BEH) & $\mathrm{BEH} 2$ & More often used & \\
\hline Students & SAT1 & Self-efficacy & \\
\hline $\begin{array}{l}\text { Satisfaction } \\
\qquad(\mathrm{SAT})\end{array}$ & SAT2 & Enjoyment & [12] \\
\hline
\end{tabular}

\section{Research Model}

We designed the framework, as displayed in figure 1. It depicts the influence between all variables.

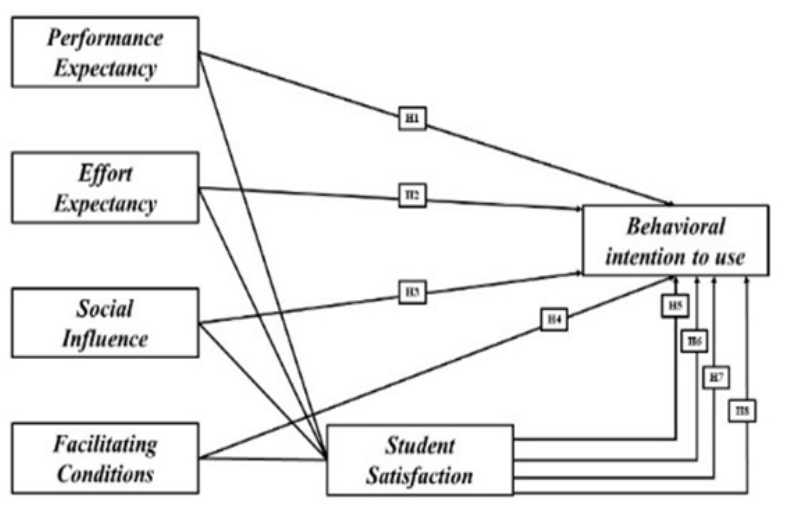

Figure 1. Research Model 
The UTAUT model is considered the most valid and up-to-date theory in technology acceptance. UTAUT model explains behavioral intentions with preeminent factors, namely PER, EFF, SOC) and FAC. PER is defined as how much students believe that using a system can help them realize work achievement benefits. This factor enormously influences behavioral intention to use technology.

EFF described the ease of use in using the systems. However, several studies found that EFF influenced users' intention to use technology [17], [18]. However, findings obtained by Zuiderwijk et al. revealed that PER had a not-so-significant effect on the intention to accept and use technology [19]. FAC is characterized as the extent to which students assume that their organization can strengthen the system usage. Relevant research proves that facilitating conditions encourage new technology intentions [20].

SOC cites the extent to which a person can know that prominent people he trusted have used the latest system. Meanwhile, previous research found that SOC has a substantial significance on the user's intention to accept technology [21], [22]. The behavioral choice to take and use e-learning $(\mathrm{BEH})$ is individuals' desire to use digital technology-based learning. BEH depends on many factors, as stated earlier, and influences the technology systems using.

\section{Hypothesis}

The hypothesis is a presumption that requires further verification. We have some hypotheses used to examine all variables, as proven in Table 3.

\section{Table 3. Hypothesis}

\begin{tabular}{||ll||}
\hline No & \multicolumn{1}{c|}{ Hypothesis } \\
H1 & PER significantly and positively affects BEH \\
H2 & EFF significantly and positively affects BEH \\
H3 & SOC significantly and positively affects BEH \\
H4 & FAC significantly and positively affects BEH \\
H5 & PER significantly and positively affects BEH \\
& mediated by SAT \\
H6 & $\begin{array}{l}\text { EFF significantly and positively affects BEH } \\
\text { mediated by SAT }\end{array}$ \\
H7 & $\begin{array}{l}\text { SOC significantly and positively affects BEH } \\
\text { mediated by SAT }\end{array}$ \\
H8 & $\begin{array}{l}\text { FAC significantly and positively affects BEH } \\
\text { mediated by SAT }\end{array}$ \\
\hline
\end{tabular}

\section{Result and Discussion}

We investigated antecedents that affect the behavioral intentions of students in applying elearning by adapting the UTAUT model. The formulated hypothesis was tested using SPSS 24 and AMOS 24. SPSS 24 confirms the questionnaire's consistency and stability, the Split-Half, and Cronbach Alpha. The value indicated by Split-Half and Cronbach Alpha on each variable was higher than 0.7 and can be said to be reliable [23]. Meanwhile, the confirmatory factor analysis (CFA) checked the validity of this study. Table 4 shows the KMO values on all variables found to be higher than 0.7 with a significance of less than 0.01 .

Table 4. Result of Reliability and Validity

\begin{tabular}{||ccccc||}
\hline \hline Variable & Split-Half & $\begin{array}{c}\text { Cronbach } \\
\text { Alpha }\end{array}$ & KMO & Sig. \\
PER & 0.858 & 0.829 & 0.814 & 0.000 \\
EEF & 0.827 & 0.825 & 0.807 & 0.000 \\
SOC & 0.779 & 0.818 & 0.781 & 0.000 \\
FAC & 0.765 & 0.845 & 0.762 & 0.000 \\
SAT & 0.778 & 0.815 & 0.786 & 0.000 \\
BEH & 0.874 & 0.758 & 0.706 & 0.000 \\
\hline
\end{tabular}

The Average Variance Extracted (AVE) value indicates a number greater than 0.50 , which is between 0.50-0.992. Therefore, the research indicators have been feasible to be used in the next stage of research. In contrast, the value of FornellLarcker indicates more than 0.70 [24]. Thus, the value proves that the value of discriminant validity is accepted. Thus, the data can be used for the next stage of research. Ave and Fornell-Larcker numbers are shown in Table 5.

Table 5. Results of Average Variance Extracted (AVE)

\begin{tabular}{||lrrrrrrr||}
\hline & AVE & PER & EFF & SOC & FAC & BEH & SAT \\
PER & 0.992 & 0.737 & & & & & \\
EFF & 0.901 & 0.693 & 0.703 & & & & \\
SOC & 0.884 & 0.196 & 0.063 & 0.825 & & & \\
FAC & 0.914 & 0.051 & 0.093 & 0.351 & 0.825 & & \\
BEH & 0.608 & 0.108 & 0.199 & 0.384 & 0.350 & 0.837 & \\
SAT & 0.500 & 0.080 & 0.021 & 0.070 & 0.044 & .039 & 0.768 \\
\hline
\end{tabular}

\section{Hypothesis Analysis}

Table 6 explains that all paths are significant $(\mathrm{p}<$ 0.050). The finding revealed that PER influenced BEH (H1). They were supported by empirical evidence that results indicated that PER affects technology use [25], [26]. This study also found that the variables EEF, SOC, and FAC affect BEH (H2, $\mathrm{H} 3$, and $\mathrm{H} 4$ ).

Table 6. Hypotheses Results

\begin{tabular}{|llllll||}
\hline Path & & & $\boldsymbol{\beta}$ & $\mathbf{p}$ & Status \\
$\mathrm{PER}$ & $\rightarrow$ & BEH & 0.610 & 0.000 & Supported \\
$\mathrm{EFF}$ & $\rightarrow$ & BEH & 0.557 & 0.000 & Supported \\
$\mathrm{SOC}$ & $\rightarrow$ & BEH & 0.722 & 0.000 & Supported \\
$\mathrm{FAC}$ & $\rightarrow$ & BEH & 0.667 & 0.000 & Supported \\
$\mathrm{PER}$ & $\rightarrow \mathrm{SAT} \rightarrow$ & $\mathrm{BEH}$ & 1.653 & 0.038 & Supported \\
$\mathrm{EFF}$ & $\rightarrow \mathrm{SAT} \rightarrow$ & $\mathrm{BEH}$ & 1.646 & 0.014 & Supported \\
$\mathrm{SOC} \rightarrow \mathrm{SAT} \rightarrow$ & $\mathrm{BEH}$ & 1.662 & 0.046 & Supported \\
$\mathrm{FAC}$ & $\rightarrow \mathrm{SAT} \rightarrow$ & $\mathrm{BEH}$ & 1.658 & 0.027 & Supported \\
\hline
\end{tabular}


In tune with the finding of research conducted by Dajani \& Abu Hegleh, Tarhini et al., this study confirms that EFF positively influences the technology used. Some research also shows that social impact influences digital information technology [27], [28]. Many people, in the surrounding area, use e-learning in learning and teaching to make other individuals believe that elearning usage is relatively easy.

The fourth hypothesis is similar to the findings of Penarroja et al. and Zuiderwijk et al., where FAC affects technology use [19], [29]. Besides that, satisfaction mediates the influence of PER, EFF, SOC, and FAC on BEH (H5, H6, H7, and H8). Research results from Mulyadi et al. demonstrate relevant research supporting these findings; [30] found that PER, EFF, SOC, and FAC on BEH use elearning through student's satisfaction.

Simultaneously, the structural model comprises three types of compatibility indexes: absolute fit measure (such as $\chi 2$, AGFI, RMSEA, GFI), CFI, and NFI. As in Table 7, all matched indices were obtained to meet the recommended range, such as CMIN/df 1.654, RMSEA 0.000, GFI 0.936, AGFI 0.932, CFI 0.935, and NFI 0.961 [31].

Table 7. Result of Structural Model of GoF

\begin{tabular}{||cccc||}
\hline Fit Index & Value & $\begin{array}{c}\text { Critical } \\
\text { Value }\end{array}$ & $\begin{array}{c}\text { Acceptability } \\
\text { CMIN/Df }\end{array}$ \\
1.654 & $<3$ & Yes \\
GFI & .936 & $\geq .90$ & Yes \\
RMSEA & .000 & $<.5$ & Yes \\
AGFI & .932 & $\geq .90$ & Yes \\
CFI & .935 & $\geq .90$ & Yes \\
NFI & .961 & $\geq .90$ & Yes \\
\hline
\end{tabular}

\section{Theoretical Contributions}

Theoretical contribution requires specific research results that can provide original insights into a phenomenon studied effectively for improving organization. This study offers an authentic insight into empirical data about the effects of PER, EFF, SOC, and FAC on BEH through student's satisfaction. Therefore, our research makes an essential contribution to the education field in tertiary institutions. This research contributes explicitly to variables that affect digital technology in learning and teaching in higher education environments.

\section{Implications for Education and Management}

The findings of this study implicate in the education and management fields. From this study note, some practical implications of these findings show that the conclusive e-learning acceptance hinge on the UTAUT model is very influential. Therefore, we advise developers of electronic learning systems by providing complete and more comfortable features. Hopefully, it will increase student's satisfaction and also improve student learning outcomes themselves. Also, we suggest that educators' digital technology in teaching and learning systems have to adapt to the subjects and provide them with learning approaches.

Secondly, the study suggested that higher education institutions can use the e-learning option to utilize e-learning effectively. To achieve this goal, educational institutions have to be responsible for providing socialization or training to students regarding the electronic learning system to use the system effectively. Therefore, universities have to assess the extent of satisfaction in applying elearning. Another implication for management is that PER, EFF, SOC, and FAC impact e-learning acceptance and student's satisfaction because technological development in education significantly affects student satisfaction. Besides, e-learning as an educational facility can provide information for student needs. For future research, this study recommends checking out other factors that can increase the acceptance and use of digital technology and student satisfaction.

\section{Conclusion}

The research objective was to verify PER, EFF, SOC, FAC on BEH based on relevant studies in the educational context. The success of higher education institutions in implementing digital technology needs to consider customer satisfaction. It is because satisfaction is an essential asset in improving the performance of related tertiary institutions. This study uses a conceptual framework about UTAUT models' influence and satisfaction in receiving and accepting electronic learning systems. The result of the testing model provides that the relationship of the study variables, namely PER, EFF, SOC, and FAC, influences the behavioral intention in using elearning through student's satisfaction. This study suggests further research to examine the influence of other essential factors identified with digital learning systems.

The research finding provides an input for lecturers to choose instructional media consonance with the material and learning models. Theoretically, this research can give lecturers knowledge about digital learning in the teaching process. This research suggests that higher education institutions offer to learn support facilities for students, such as providing a broader place to learn and upgrade the system according to the latest technological trends. At present, the use of e-learning is essential for every university to have. Besides, researchers also provide recommendations for further research with all educational institutions ranging from primary education to higher education. 


\section{References}

[1]. Tierney, W. M., Sidle, J. E., Diero, L. O., Sudoi, A., Kiplagat, J., Macharia, S., ... \& Wools-Kaloustian, K. (2016). Assessing the impact of a primary care electronic medical record system in three Kenyan rural health centers. Journal of the American Medical Informatics Association, 23(3), 544-552. https://doi.org/10.1093/jamia/ocv074

[2]. Samsuri, N. N., Nadzri, F. A., \& Rom, K. B. M. (2014). A study on the student's perspective on the effectiveness of using e-learning. Procedia-Social and Behavioral Sciences, 123, 139-144. https://doi.org/10.1016/j.sbspro.2014.01.1407

[3]. Keller, C., \& Cernerud, L. (2002). Students' perceptions of e-learning in university education. Journal of Educational Media, 27(1-2), 5567. https://doi.org/10.1080/1358165020270105

[4]. Gunasekaran, A., McNeil, R. D., \& Shaul, D. (2002). E-learning: research and applications. Industrial and Commercial Training, 34(2), 44-53. https://doi.org/10.1108/00197850210417528

[5]. Al-Shihi, H., Sharma, S. K., \& Sarrab, M. (2018). Neural network approach to predict mobile learning acceptance. Education and Information Technologies, 23(5), 1805-1824.

https://doi.org/10.1007/s10639-018-9691-9

[6]. Sánchez-Prieto, J. C., Huang, F., Olmos-Migueláñez, S., García-Peñalvo, F. J., \& Teo, T. (2019). Exploring the unknown: The effect of resistance to change and attachment on mobile adoption among secondary preservice teachers. British Journal of Educational Technology, 50(5), 2433-2449. https://doi.org/10.1111/bjet.12822

[7]. Sánchez-Elvira Paniagua, A., \& Simpson, O. (2018). Developing student support for open and distance learning: The EMPOWER project. Journal of Interactive Media in Education, 2018(1). https://doi.org/10.5334/jime.470

[8]. Venkatesh, V., Morris, M. G., Davis, G. B., \& Davis, F. D. (2003). User acceptance of information technology: Toward a unified view1.MIS Quarterly, 27(3), 425.

[9]. Weerasinghe, I. S., \& Fernando, R. L. (2017). Students' satisfaction in higher education. American Journal of Educational Research, 5(5), 533-539. https://doi.org/10.12691/education-5-5-9

[10]. Kara, S. (2020). Investigation of Job Satisfaction and Burnout of Visual Arts Teachers. International Journal of Research in Education and Science, 6(1), 160-171. https://doi.org/10.46328/ijres.v6i1.817

[11]. Reichenberg, M., \& Löfgren, K. (2019). On the Relationship between Swedish Special Educators' Work Absenteeism, Job Satisfaction, and SelfEfficacy for Inclusive Education. International Journal of Research in Education and Science, 5(2), 615-627.

[12]. Zaied, A. N. H. (2012). An integrated success model for evaluating information system in public sectors. Journal of Emerging Trends in Computing and Information Sciences, 3(6), 814-825.
[13]. Al-Emran, M., Mezhuyev, V., \& Kamaludin, A. (2018). Technology Acceptance Model in M-learning context: A systematic review. Computers \& Education, 125, 389-412.

https://doi.org/10.1016/j.compedu.2018.06.008

[14]. Aburub, F., \& Alnawas, I. (2019). A new integrated model to explore factors that influence adoption of mobile learning in higher education: An empirical investigation. Education and Information Technologies, 24(3), 2145-2158. https://doi.org/10.1007/s10639-019-09862-x

[15]. Almaiah, M. A., \& Alismaiel, O. A. (2019). Examination of factors influencing the use of mobile learning system: An empirical study. Education and Information Technologies, 24(1), 885-909. https://doi.org/10.1007/s10639-018-9810-7

[16]. Venkatesh, V., Thong, J. Y., \& Xu, X. (2012). Consumer Acceptance and Use of Information Technology: Extending the Unified Theory of Acceptance and Use of Technology. MIS Quarterly, 36(1), 157-178. https://doi.org/10.1109/MWSYM.2015.7167037

[17]. Becker, D. (2016). Acceptance of mobile mental health treatment applications. Procedia Computer Science, 98, 220-227. https://doi.org/10.1016/j.procs.2016.09.036

[18]. Kalavani, A., Kazerani, M., \& Shekofteh, M. (2018). Acceptance of evidence based medicine (EBM) databases by Iranian medical residents using unified theory of acceptance and use of technology (UTAUT). Health Policy and Technology, 7(3), 287292. https://doi.org/10.1016/j.hlpt.2018.06.005

[19]. Zuiderwijk, A., Janssen, M., \& Dwivedi, Y. K. (2015). Acceptance and use predictors of open data technologies: Drawing upon the unified theory of acceptance and use of technology. Government Information Quarterly, 32(4), 429-440. https://doi.org/10.1016/j.giq.2015.09.005

[20]. Garavand, A., Mohseni, M., Asadi, H., Etemadi, M., Moradi-Joo, M., \& Moosavi, A. (2016). Factors Influencing the Adoption of Health Information Technologies: A Systematic Review. Electronic physician, 8(8), 2713-2718. https://doi.org/10.19082/2713

[21]. Chiu, Y. L., \& Tsai, C. C. (2014). The roles of social factor and internet self-efficacy in nurses' web-based continuing learning. Nurse Education Today, 34(3), 446-450. https://doi.org/10.1016/j.nedt.2013.04.013

[22]. Guo, X. T., Yuan, J. Q., Cao, X. F., \& Chen, X. D. (2012, September). Understanding the acceptance of mobile health services: A service participants analysis. In 2012 International Conference on Management Science \& Engineering 19th Annual Conference Proceedings (pp. 1868-1873). IEEE. https://doi.org/10.1109/ICMSE.2012.6414426

[23]. Hair, Joseph F, Black, J. W. C., Babin, B. J., \& Aderson, R. E. (2014). Multivariate data analysis. USA: British Library Cataloguing in Publication Data.

[24]. Fornell, C., \& Larcker, D. F. (1981). Evaluating structural equation models with unobservable variables and measurement error. Journal of Marketing Research, 18(1), 39-50. 
[25]. Shetty, B. R. (2018). Gap Analysis of Students' experience and Expectations with Special Reference to Mba Education in India. PUPIL: International Journal of Teaching, Education and Learning, 2(2). https://doi.org/10.20319/pijtel.2018.22.3550

[26]. Zainul, M. M., Kusyanti, A., \& Aryadita, H. (2018). Analisis Faktor-Faktor Yang Memengaruhi Kepercayaan Dan Resiko Pengguna Dalam Bertransaksi Pada E-Commerce XYZ Menggunakan UTAUT ( Unified Theory Of Acceptance And Use Of Technology). Jurnal Pengembangan Teknologi Informasi Dan Ilmu Komputer (J-PTIIK) Universitas Brawijaya, 2(7), 2584-2593.

[27]. Lin, C. H., Yang, S. C., \& Sung, Y. K. (2014). Gender differences in intention and relationship among factors of using Facebook for collaboration. African Journal of Business Management, 8(18), 801-809. https://doi.org/10.5897/AJBM2011.1234

[28]. Lwoga, E. T., \& Lwoga, N. B. (2017). User Acceptance of Mobile Payment: The Effects of UserCentric Security, System Characteristics and Gender. The Electronic Journal of Information Systems in Developing Countries, 81(1), 1-24. https://doi.org/10.1002/j.1681-4835.2017.tb00595.x
[29]. Peñarroja, V., Sánchez, J., Gamero, N., Orengo, V., \& Zornoza, A. M. (2019). The influence of organisational facilitating conditions and technology acceptance factors on the effectiveness of virtual communities of practice. Behaviour \& Information Technology, 38(8), 845-857. https://doi.org/10.1080/0144929X.2018.1564070

[30]. Yudong, T., Aman, M. S., Hooi, L. B., \& Siswantoyo, S. (2020). Satisfaction Evaluation Model Of High-Level Athletes Management System in Universities of Sichuan Province of China. Jurnal Cakrawala Pendidikan, 39(1), 26-38. https://doi.org/10.21831/cp.v39i1.24559

[31]. Hair, J. F., Sarstedt, M., Ringle, C. M., \& Mena, J. A. (2012). An assessment of the use of partial least squares structural equation modeling in marketing research. Journal of the academy of marketing science, 40(3), 414-433.

https://doi.org/10.1007/s11747-011-0261-6 